\title{
Effect of Peptidic Groups \\ Isolated from Enzymic Casein Hydrolysate on Growth and Toxinogenesis of Clostridium welchii (perfringens)
}

\author{
By KATEŘINA NEKVASILOVÁ, J. ŠÍDLO AND J. HÁZA \\ Institute of Sera and Vaccines, Praha Io, Czechoslovakia
}

(Accepted for publication 20 January 1970)

\begin{abstract}
SUMMARY
Enzymic casein hydrolysate, which is a suitable nitrogenous basis of the medium for alpha-toxin production by Clostridium welchii (perfringens), was fractionated by column chromatography on Sephadex G25 gel, using ammoniacal buffer. Combined peptidic fractions were able to support microbial growth, though toxin production was minimal. Toxinogenic substances were retained on the gel and could be eluted with weak acetic acid. This active substance represented about $0.5 \%$ of the original hydrolysate and consisted of a mixture of low molecular weight peptides with free amino acids and a mineral portion (calcium, magnesium and iron). When column chromatography of enzymic casein hydrolysate was done with Sephadex G 25 and $0.05 \mathrm{M}$-ammonium hydrogen carbonate buffer, toxinogenic substances were not retained on the gel. The procedure resulted in a group separation of peptides according to their molecular weight and simultaneously an adsorption effect was observed of aromatic amino acids on the gel. Four fractions were obtained exhibiting different effects on growth and toxinogenesis by $C$. welchii.

The fraction containing the largest molecules and the major part of total nitrogen ( $90 \%$ approx.) proved to stimulate microbial growth, though only minimal $\alpha$-toxin production. The other three low molecular fractions exhibit a stimulating effect on $\alpha$-toxin production; their amino acid compositions were different.

The most active of the low molecular weight fractions contained about $\mathrm{I} .8 \%$ of the initial nitrogen and could be fractionated with DEAE-Sephadex A 25 into a further four groups of which the most remarkable was peptidebound tyrosine.

Gel chromatography on Sephadex columns resulted in an unequal distribution of $\mathrm{Fe}$ ions among the fractions; this was allowed for in performing comparative microbiological tests.
\end{abstract}

\section{INTRODUCTION}

It has been shown repeatedly that some synthetic media gave good growth of Clostridium welchii (perfringens) without any $\alpha$-toxin production (Taylor \& Stewart, I94I ; Boyd, Logan \& Tytell, I948). The production of toxin was determined or strongly stimulated by the presence of muscular extracts (Macfarlane \& Knight, I94I ; Logan, Tytell, Danielson \& Griner, I945) or by the presence of enzymic protein hydrolysates (Adams, Hendee \& Pappenheimer, 1947; Boyd et al. 1948; Murata, Yamada \& Kameyama, 1958). The distinct nature of these toxinogenic nitrogenous substances was not clarified. Rogers \& Knight (I946) concluded that the active substance obtained from an extract of horse meat had the character of an amino sugar. Experiments 
aimed at isolating toxinogenic substances from enzymic digests of casein and gelatin using different separation methods revealed their presence in several fractions; the active substances were dialyzable (Adams et al. 1947). Jayko \& Lichstein (I959) showed a stimulating capacity of some of the 29 synthetic dipeptides tested, especially glycyl-L-asparagine. Murata et al. (1958) isolated from a dialysate of commercial peptone a so-called 'methanol-insoluble factor' which contained different peptides as well as other unidentified components. Stavri, Bittner \& Ficiu (I964) obtained best toxin yields by using meat hydrolysates by extreme enzymic digestion. The above results obviously indicated that there probably exist several toxinogenic factors of peptide nature, all being low-molecular dialysable compounds. We expected that a fractionation of the peptides contained in enzymic casein hydrolysate based on the principle of different molecular weight might contribute to a more accurate characterization of toxinogenic factors. This is why enzymic digests were fractionated by gel chromatography on Sephadex columns, followed by a study of the effect of the fractions obtained on the growth and toxinogenesis of $C$. welchii. It was the aim of this study to give a biochemical characterization of the fractions, in particular of the group exhibiting the most pronounced toxinogenic effect. Special attention was paid to the adsorption of the stimulating substances on gel.

\section{METHODS}

Culture medium. Semi-defined medium was used according to Adams \& Hendee (1945) containing in a $100 \mathrm{ml}$. volume: pancreatic casein digest, $50 \mathrm{ml}$.; $\mathrm{Na}_{2} \mathrm{HPO}_{4}$. I $2 \mathrm{H}_{2} \mathrm{O}, 0.584$ g.; $\mathrm{KH}_{2} \mathrm{PO}_{4}, 0.05$ g. $; \mathrm{MgSO}_{4} .7 \mathrm{H}_{2} \mathrm{O}$, 0.016 g.; soluble starch, $0.22 \mathrm{~g}$; $\mathrm{pH} 7.6$ to $7 \cdot 7$. For the preparation of the digest the methods by the above authors were adopted, the sole difference being that the hydrolysis of casein proceeded with continuous stirring. In experimental media casein digest was replaced by peptide fractions obtained by gel chromatography. Freeze-dried fractions were dissolved in distilled water and made up to the initial volume of the fractionated hydrolysate. The media were filled $35 \mathrm{ml}$. into wide test-tubes, after adding pieces of cotton-wool sterilized in steam for $40 \mathrm{~min}$.

Organism. Clostridium welchii (perfringens) BP $6 \mathrm{~K}$ type A preserved on tryptically digested meat broth containing $0.5 \%$ glucose, in two passages ( 8 and $8 \mathrm{~h}$.) at $37^{\circ}$. The second passage was used for inoculating semi-defined medium.

Cultivation. After cooling the medium to $37^{\circ}, 0.5 \%$ glucose was added together with $2 \%(\mathrm{v} / \mathrm{v})$ inoculum from the second passage of the strain. Incubation was done in two parallel series for $8 \mathrm{~h}$. at $37^{\circ}$. Lecithinase content was determined in the supernatant fluid of the cultures obtained by $20 \mathrm{~min}$. centrifuging at $3000 \mathrm{~g}$.

Growth. This was determined by measuring extinction after diluting the suspension with physiological saline to I/50. Pulfrich colorimeter, blue filter, light path $5 \mathrm{~cm}$. $E_{5 \mathrm{~cm}}$ values were converted by a calibrating curve to $10^{9}$ organisms $/ 1 \mathrm{ml}$. bacterial suspension.

Lecithinase determination. Determinations were done in vitro, using the lecithovitelline test (van Heyningen, I94I; Kémeny \& Illés, I952) at $0.2 \mathrm{u} . \alpha$ level (Lv); the results were converted to I $u . \alpha$ level. As standard, purified horse serum globulin was used, its titre being determined by a comparison with international standard antiperfringens serum from Copenhagen.

Fractionation of pancreatic casein digest. Gel chromatography was done in two ways. (a) In alkaline medium according to Phillips \& Gibbs (I96I). A $50 \mathrm{ml}$. volume of 
pancreatic casein digest (PCD) was filtered through a column of Sephadex G 25 medium (Pharmacia, Uppsala); size of the column $5 \times 50 \mathrm{~cm}$.; elution buffer $0.2 \mathrm{M}$-ammonia; fractions were collected in an automatic collector, flow rate 5 to $6 \mathrm{ml} . / 10 \mathrm{~min}$.; line shift $10 \mathrm{~min}$. Colorimetric evaluation was done in $0.1 \mathrm{ml}$. from each fraction by the Folin method modified by Lowry et al. (I95I). Measurements were made with a 'Prema' photometer of Czechoslovak make, at $520 \mathrm{~nm}$.; light path $\mathrm{I} \mathrm{cm}$.; results are expressed in $\%$ of light transmitted. The fractions forming the individual peaks were freeze-dried. (b) In weakly alkaline medium, $50 \mathrm{ml}$. of PCD were deposited on a $5 \times 100$ $\mathrm{cm}$. column of Sephadex G25, elution with $0.05 \mathrm{M}$-ammonium hydrogen carbonate ( $\mathrm{pH} 76$ ). The fractions were collected automatically, flow rate about $45 \mathrm{drops} / \mathrm{min}$., line displacement $20 \mathrm{~min}$. From each of about 150 fractions, $\mathrm{O} \cdot \mathrm{I} \mathrm{ml}$. samples were withdrawn and evaluated as described above. Fractions from each peak were freezedried. Fractionation was at $4^{\circ}$.

Fractionation of active peptide and amino acid groups on ion exchange gel. Fractionations were made by gradient elution with a linear $\mathrm{pH}$ change according to Carnegie (196I). A glass column, size $\mathrm{I} \times 20 \mathrm{~cm}$., was filled with DEAE-Sephadex A 25 in acetate form and brought to equilibrium with $0 \cdot \mathrm{I}$ M-collidine acetate buffer $(\mathrm{pH} 7.8$ to 7.9 ). I2. I g. collidine distilled in vacuo, were dissolved in about $750 \mathrm{ml}$. distilled water, $\mathrm{pH}$ adjusted to 7.8 to 7.9 with $10 \%$ acetic acid and the volume made to I000 $\mathrm{ml}$.

Freeze-dried fractions obtained by PCD fractionation on Sephadex G 25 (elution buffer $0.05 \mathrm{M}-\mathrm{NH}_{4} \mathrm{HCO}_{3}$ ) were dissolved in $20 \mathrm{ml}$. physiological saline and $2 \mathrm{ml}$. of the solution (containing $\mathrm{I} \cdot 2 \mathrm{mg}$. total $\mathrm{N}$ ) were applied to the column. Elution was effected with collidine acetate buffer, started at $\mathrm{pH} 7 \cdot 8 ; \mathrm{pH}$ gradient was obtained by gradual mixing with $\mathrm{O} \cdot \mathrm{I} \mathrm{M}$-acetic acid, while M-acetic acid was used from the 49 th test-tube on. The fractions were taken by an automatic collector, line displacement Io min., volume of fractions $2.5 \mathrm{ml}$. About $\mathrm{I} 20$ fractions were collected. Detection was made in I ml. samples from each test-tube, with ninhydrin reagent, using Rosen's modification ( I957) of Moore \& Stein's technique. The colour was measured with a Zeiss spectrometer, light path $\mathrm{I} \mathrm{cm}$., $520 \mathrm{~nm}$. and expressed as \% of light transmitted.

Paper chromatography of peptides and amino acids. For preparatory fractionations Whatman no. 3 paper was used. Several equal samples were spotted side by side and eluted in a descending way in an $n$-butanol + acetic acid + water solvent system $(\mathrm{IOO}+9+30$ by vol.). The outer strip of paper was cut off and developed by $0.2 \%$ solution of ninhydrin in $n$-butanol. The remaining strips of paper were cut into several zones. The paper strips showing an identical group of ninhydrin-positive substances were stitched together and eluted with water as described by Vaněček (1961). The eluate was concentrated on silicon-coated watch glasses and subjected to paper chromatography.

Analytical chromatography was done on Whatman no. I paper, in a descending one-dimensional way, in an $n$-butanol + acetic acid + water solvent $(100+9+30$ by vol.) and in a phenol + water solvent in $\mathrm{NH}_{3}$ atmosphere. Detection with $0.2 \%$ ninhydrin in $n$-butanol. The identity of amino acids was verified with the following specific reagents: tryptophane with Ehrlich's reagent in Sprince's modification (I960), tyrosine with Pauly's agent (Hais \& Macek, I959), arginine according to Takaguchi (Hais \& Macek, 1959), cysteine with a solution of $\mathrm{Na}$ nitroprusside $+\mathrm{NaCN}$, methionine with potassium iodoplatinate. 
Hydrolysis of peptides. The samples were hydrolysed with $6 \mathrm{~N}-\mathrm{HCl}$ in sealed vials, at $105^{\circ}$ for $\mathrm{I} 8 \mathrm{~h}$.; $\mathrm{HCl}$ excess was removed by repeated evaporation on silicon-coated watch glasses.

Total nitrogen was determined by the Kjeldahl method.

Amino nitrogen was determined by using the iodometric technique according to Schroeder, Kay \& Mills (1950).

Iron determination. After incineration with sulphuric and perchloric acids, Fe was reduced with ascorbic acid to $\mathrm{Fe}^{2+}$. The pink colouring resulting from the formation of a complex with $O$-phenanthrolin was measured colorimetrically at $498 \mathrm{~nm}$.

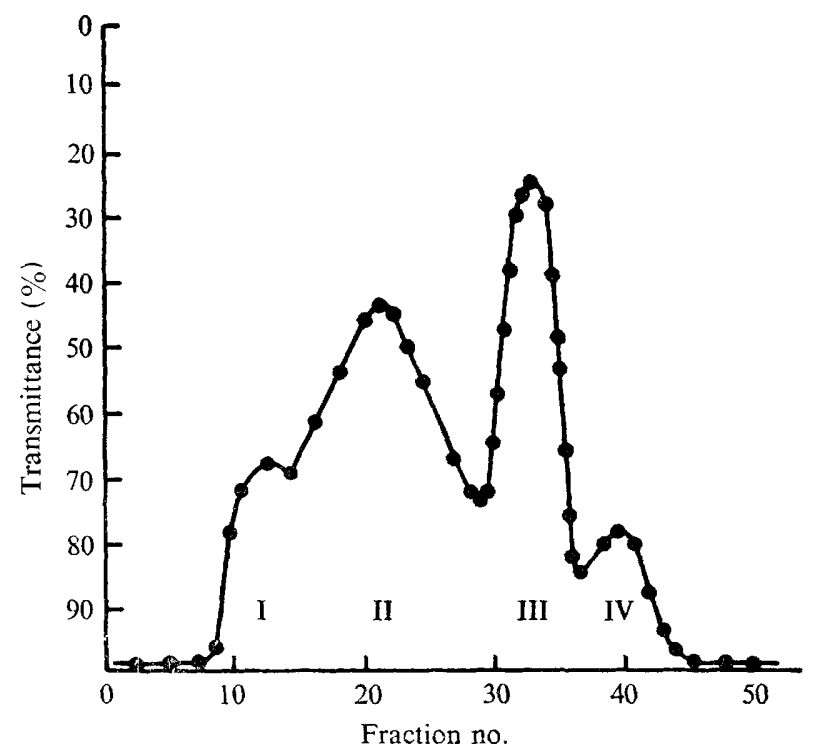

Fig. I. Pancreatic casein digest filtered through a column $(5 \times 50 \mathrm{~cm}$.) of Sephadex $\mathrm{G} 25$. Sample applied $50 \mathrm{ml}$., elution with $0.2 \mathrm{M}-\mathrm{NH}_{3}$, fractions collected at a flow rate of about 60 $\mathrm{ml}$./h. Detection by the Folin-Ciocalteu reagent according to Lowry et al. (I95I), absorbancy at $520 \mathrm{~nm}$.

\section{RESULTS}

Fractionation of pancreatic casein digest $(P C D)$ in ammoniacal medium. The fractionation of the digest which represented the only nitrogenous material of the medium was done, in the first experimental series, on Sephadex G 25 columns with an ammoniacal eluant by the method of Phillips \& Gibbs (196I). The separation of peptides, though somewhat imperfect, was meant to provide orientating information on the effect of different groups on $\alpha$-toxin production (Fig. I).

Effect of fractions on growth and toxinogenesis. In the culture medium PCD was replaced with various mixtures of freeze-dried peptide fractions. Experiments made by eliminating procedures were unsuccessful; the growth as well as production of $\alpha$-toxin in all media appeared to be weaker than in the control medium and even a mixture of all four fractions did not induce the initial degree of toxin formation (Table I). The above results changed the direction of the experimental work, showing that the decrease of growth and toxinogenesis must be sought in adsorption of active factors on gel. 
Retardation of toxinogenic substances on gel. The retarded substances were eluated after the passage of the last ninhydrin-positive components with 41 . of 0.1 M-acetic acid. The acidic eluate was concentrated in vacuum and freeze-dried. From $100 \mathrm{ml}$. initial PCD 55 to $60 \mathrm{mg}$. dry matter were obtained, representing about $0.5 \%$ of the dry matter contained in PCD. On addition of the acetic eluate to the combined $\mathrm{NH}_{3}$ fractions nos. I to IV $\alpha$-toxin titres were about doubled, but did not attain the titres of the control cultures. A stimulating effect was also observed on the growth of the strain (Table 2).

Table I. Growth and $\alpha$-toxin production by Clostridium welchii in media prepared from fractions obtained by gel chromatography of pancreatic casein digest $(P C D)$ on Sephadex $\mathrm{G} 25$ columns, eluant $0 \cdot 2 \mathrm{M}-\mathrm{NH}_{3}$

\begin{tabular}{|c|c|c|c|}
\hline Nitrogen source & $\begin{array}{l}\text { Total N } \\
\text { g. } / 100 \mathrm{ml} \text {. }\end{array}$ & $\begin{array}{c}\text { Microbial count } \\
\times 10^{-9} / \mathrm{ml} .\end{array}$ & $\mathrm{Lv} / \mathrm{u} . \alpha / \mathrm{ml}$. \\
\hline PCD (control) & 0.64 & $1 \cdot 2$ & $5 \cdot 0$ \\
\hline Fraction $\mathrm{I}+\mathrm{II}+\mathrm{III}+\mathrm{IV}$ & $0.6 \mathrm{I}$ & $4 \cdot 9$ & $1 \cdot 6$ \\
\hline $\mathrm{I}+\mathrm{II}+\mathrm{III}$ & 0.58 & $4 \cdot 5$ & $1 \cdot 2$ \\
\hline$I+I I I+I V$ & 0.50 & $5 \cdot 0$ & I.2 \\
\hline$I+I I I+I V$ & 0.35 & $3 \cdot 1$ & $<\mathrm{I} \cdot \mathrm{O}$ \\
\hline $\mathrm{I}+\mathrm{II}+\mathrm{IV}$ & 0.36 & $2 \cdot 8$ & $<\mathrm{I} \cdot \mathrm{O}$ \\
\hline
\end{tabular}

Table 2. Effect of gel-retarded substances on growth and $\alpha$-toxin production

Sephadex G 25 column, eluant $0 \cdot 2 \mathrm{M}-\mathrm{NH}_{3}$, subsequent elution with $\mathrm{O} \cdot \mathrm{I}$ M-acetic acid. Results of 2 Expts. A and B, given as average of 2 replicas.

\begin{tabular}{|c|c|c|c|c|c|c|c|c|}
\hline \multirow[t]{2}{*}{ Nitrogen source } & \multicolumn{2}{|c|}{$\begin{array}{l}\text { Total N } \\
\text { g./ IOO ml. }\end{array}$} & \multicolumn{2}{|c|}{$\begin{array}{c}\text { Microbial count } \\
\times 10^{-9} / \mathrm{ml}\end{array}$} & \multicolumn{2}{|c|}{$\mathrm{Lv} / \mathrm{u}, \alpha / \mathrm{ml}}$. & \multicolumn{2}{|c|}{$\begin{array}{l}\mathrm{Lv} / \mathrm{u} . \alpha / \mathrm{IO}^{9} \\
\text { microbes }\end{array}$} \\
\hline & A & B & A & B & A & $\mathbf{B}$ & A & B \\
\hline PCD (control) & 0.66 & 0.73 & I I $\cdot 5$ & II $\cdot 5$ & $8 \cdot 0$ & $6 \cdot 4$ & 0.69 & 0.55 \\
\hline Fractions I-IV & 0.58 & 0.68 & $4 \cdot 5$ & $6 \cdot 5$ & $1 \cdot 6$ & $1 \cdot 2$ & 0.35 & $0 \cdot 18$ \\
\hline $\begin{array}{l}\text { Fractions I-IV + acetic } \\
\text { eluate }\end{array}$ & $0.6 I$ & 0.73 & $6 \cdot 0$ & $8 \cdot 9$ & $3 \cdot 2$ & $3 \cdot 2$ & 0.53 & 0.36 \\
\hline
\end{tabular}

Table 3. Effect of acetic eluate and its mineral component on growt $h_{\mathrm{a}}^{*}$ and $\alpha$-toxin production

Fractionation of PCD on Sephadex G 25, elution buffer $0.2 \mathrm{M}-\mathrm{NH}_{3}$, extraction of adsorbed substances with $\mathrm{O} \cdot \mathrm{I} \mathrm{M}$-acetic acid.

Nitrogen source

PCD (control)

Fractions I-IV

Fractions I-IV + acetic eluate

Fractions I-IV + mineral component of acetic eluate

Fractions $\mathrm{I}-\mathrm{IV}+\mathrm{Fe}^{2+}$

$\begin{array}{cc}\text { Iron } & \begin{array}{c}\text { Microbial } \\ \text { count } \times\end{array} \\ \mu \mathrm{g} . / \mathrm{ml} . & 10^{-9} / \mathrm{ml} . \\ 3.2 & 13 \cdot 2 \\ 1.0 & 6 \cdot 2 \\ 1 \cdot 4 & 8.1 \\ 1 \cdot 3 & 8 \cdot 7 \\ 3.1 & 10 \cdot 0\end{array}$

Microbial

Analysis of the substances retarded on gel. The incineration of the combined freezedried acetic eluates from 20 column fractionations revealed that $55 \mathrm{mg}$. dry matter from $100 \mathrm{ml}$. initial PCD contained $30 \mathrm{mg}$. ash. As PCD contained a total of $\mathrm{I} \cdot \mathrm{I}$ to $\mathrm{I} \cdot 2 \%(\mathrm{w} / \mathrm{v})$ mineral substances this result meant that about $2.5 \%(\mathrm{w} / \mathrm{w})$ of the initial quantity of mineral substances remained adsorbed on the gel after elution with $0.2 \mathrm{M}-$ $\mathrm{NH}_{3}$. Analysis of the ash showed the presence of magnesium, calcium and iron. Of 
the original quantity of $7.8 \mu \mathrm{g}$. iron $/ \mathrm{ml}$. PCD, only $2.4 \mu \mathrm{g}$. were found in I ml. of combined $\mathrm{NH}_{3}$ fractions (I to IV) and $2.9 \mu \mathrm{g}$. in I ml. acetic acid eluate. Iron values found in the medium were usually lower (Table 3 ) than those which corresponded to the concentrations in the eluates, because of Fe losses during the preparation of media due to adsorption on flocculating phosphates which were removed by filtration.

Freeze-dried acetic acid eluate contained $\mathrm{I} \cdot 9 \%$ total $\mathrm{N}$ and was ninhydrin- and Folin-positive. By preparative chromatography on Whatman no. 3 paper in an $n$-butanol + acetic acid + water solvent peptides and amino acids were separated into I I ninhydrin-positive substances. The six separated zones were eluated, hydrolysed with $6 \mathrm{~N}-\mathrm{HCl}$ and chromatographed on Whatman no. I paper (Pl. I). The peptides were split by acid hydrolysis into several amino acids with a marked content of aspartic acid, serine + glycine, glutamic acid, threonine, alanine and other amino acids in all zones. Several aromatic acids were found, such as tyrosine, phenylalanine and tryptophane before hydrolysis. The nitrogenous proportion of the eluate obviously represents a mixture of peptides and amino acids.

The effect of the mineral and organic compounds of acetic acid extract on toxinogenesis. The effect was studied of the mineral component of acetic acid eluate and compared with the action of complete eluate. In another group of media the mineral component was replaced with $0.1 \% \mathrm{FeSO}_{4} \cdot 7 \mathrm{H}_{2} \mathrm{O}$ solution in a quantity corresponding to the deficient $\mathrm{Fe}$ concentration (Table 3). The results indicated that the stimulating effect of the acetic acid eluate was due in part only to its mineral component, i.e. essentially to $\mathrm{Fe}$ ions. Identification of the active substance in so small a quantity of the complex mixture of ninhydrin-positive substances was extremely tedious; therefore, in the following experiments, a fractionation technique was adopted which enabled group fractionation of peptides without undesirable retardation of toxinogenic substances on gel.

Fractionation of pancreatic casein digest $(P C D)$ in a weakly alkaline medium. Quantities of $50 \mathrm{ml}$. PCD were fractionated on Sephadex G 25 column, elution with $0.05 \mathrm{M}$-ammonium hydrogen carbonate $(\mathrm{pH} 7 \cdot 6)$. Freeze-dried fractions were used for biochemical and microbiological characterization. The elution curve is shown in Fig. 2.

Effect of fractions on growth and toxinogenesis. The results of the tests with media prepared of variously combined fractions showed (Table 4) that the mixed four fractions gave a toxin production equal to the control medium. The first fraction caused a good growth but slight toxin production only; it contained about $85 \%$ of the substances present in the PCD. Its admixture with fractions II + III increased the titres to the initial values. The fourth fraction stimulated growth but only a slight increase of toxin production. Low-molecular fractions II to IV could be tested only in admixture with fraction I which represented a nutritional nitrogen source for microbial multiplication. In all media the Fe content was somewhat decreased, though its $\mathrm{I} \mu \mathrm{g}$. $\mathrm{Fe} / \mathrm{ml}$. was sufficient for full toxinogenesis.

To eliminate a potential influence of different Fe values (Pappenheimer \& Shaskan, I944; Shankar \& Bard, 1952) further experimental series were done in media the Fe contents of which were adjusted to the value of the control medium. The results (Table 5) indicated that the medium prepared from fraction I showed again a low $\alpha$-toxin formation, although the difference was less marked than in the above experiments (Table 4). Each of the low-molecular weight groups was capable of stimulating toxin production, most notably fraction III; the absence of fractions II and IV exerted no 


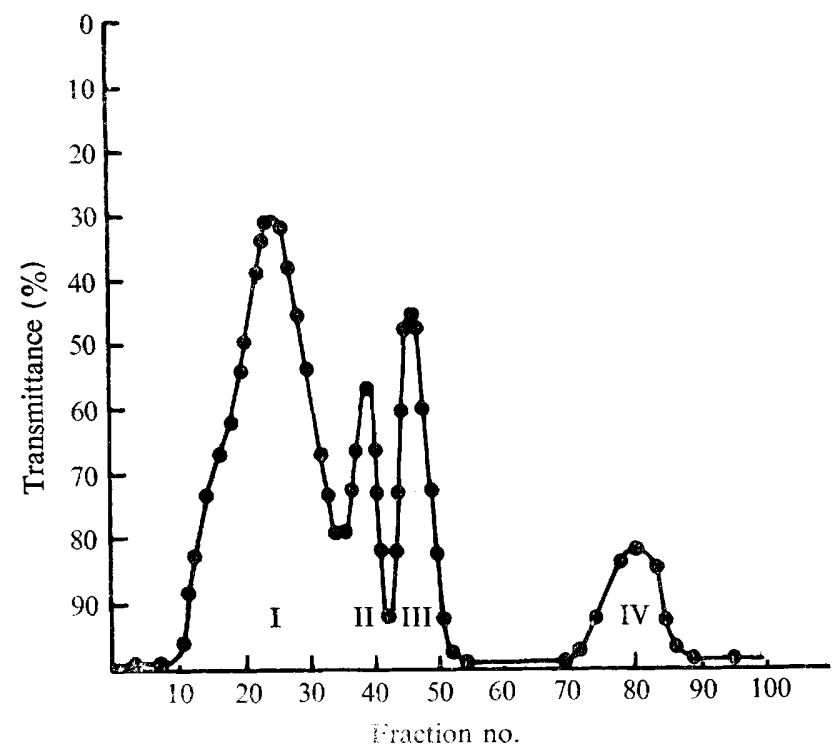

Fig. 2. Pancreatic casein digest filtered through a column $(5 \times 100 \mathrm{~cm}$.) of Sephadex $\mathrm{G} 25$. A $50 \mathrm{ml}$. sample was applied, eluant $0.05 \mathrm{M}-\mathrm{NH}_{4} \mathrm{HCO}_{3}$, fractions collected at a flow rate of about $60 \mathrm{ml}$./h. Detection-see Fig. I.

Table 4. Effect of peptidic fractions on growth and toxin production by Clostridium welchii

Fractionation of PCD on Sephadex G 25, elution buffer $0.05 \mathrm{M}-\mathrm{NH}_{4} \mathrm{HCO}_{3}$.

Nitrogen source

Microbial

Iron count $x$

PCD $\mu \mathrm{g} . / \mathrm{ml}$. $10^{-9} / \mathrm{ml}$.

Lv/u. $\alpha / \mathrm{ml}$.

Fractions I+ II + III + IV

$4 \cdot 5$
$I \cdot I$
$I \cdot 3$
$I \cdot 0$
$I \cdot 3$

I0.9
9.8
8.4
9.8
10.4

$5 \cdot 0$

5.0

$1 \cdot 6$

$5 \cdot 0$

$2 \cdot 4$ microbes

Fractions I+II + III

Fraction I+IV

I 3

Table 5. Effect of peptidic fractions of PCD on growth and $\alpha$-toxin production by Clostridium welchii

Fractionation of PCD on Sephadex $\mathrm{G}_{25}$, elution buffer $0.05 \mathrm{M}-\mathrm{NH}_{4} \mathrm{HCO}_{3}$. Iron levels in media were made up to the value of the control experiment.

\begin{tabular}{|c|c|c|c|c|}
\hline Nitrogen source & $\begin{array}{c}\text { Iron } \\
\mu \mathrm{g} . / \mathrm{ml} \text {. }\end{array}$ & $\begin{array}{c}\text { Microbial } \\
\text { count } \times \\
10^{-9} / \mathrm{ml} \text {. }\end{array}$ & $\mathrm{Lv} / \mathrm{u} . \alpha / \mathrm{ml}$. & $\begin{array}{c}\mathrm{Lv} / \mathrm{u} . \alpha / \mathrm{Io}^{9} \\
\text { microbes }\end{array}$ \\
\hline PCD (control) & $3 \cdot 4$ & 13.7 & $6 \cdot 2$ & 0.45 \\
\hline Fraction I & 3.4 & $9 \cdot 2$ & $2 \cdot 0$ & 0.22 \\
\hline I+II & $3 \cdot 4$ & II $\cdot 8$ & $4 \cdot 0$ & 0.34 \\
\hline$I+I I I$ & $3 \cdot 3$ & $8 \cdot 6$ & $6 \cdot 2$ & 0.72 \\
\hline$I+I V$ & 3.0 & $9 \cdot 3$ & $3 \cdot 2$ & 0.34 \\
\hline$I+I I+I I I$ & $3 \cdot 0$ & 9.8 & 6.2 & 0.63 \\
\hline $\mathrm{I}+\mathrm{II}+\mathrm{III}+\mathrm{IV}$ & $3 \cdot 1$ & $I I \cdot I$ & $5 \cdot 0$ & 0.63 \\
\hline
\end{tabular}


influence on titre values. These results are shown best by expressing the amount of toxin produced per $10^{9}$ organisms. The different fractions obtained by gel chromatography, in particular the most active of them, were characterized biochemically.

Contents of dry matter, nitrogen and amino-nitrogen. The determinations were made after mixing identical peak material from 5 gel preparations. Table 6 shows that the major part of the total $\mathrm{N}$ was concentrated in the first peak. The most active, i.e. the third fraction, contained only about $2 \%$ of the initial total $\mathrm{N}$.

Table 6. Contents of dry matter and nitrogenous substances in PCD fractions obtained by gel chromatography on Sephadex $\mathrm{G} 25$ medium, elution buffer $0.05 \mathrm{M}-\mathrm{NH}_{4} \mathrm{HCO}_{3}$

\begin{tabular}{|c|c|c|c|c|c|c|}
\hline \multirow[b]{2}{*}{ Fraction no. } & \multirow[b]{2}{*}{$\begin{array}{l}\text { Dry matter } \\
\mathrm{mg} / \mathrm{I} 00 \mathrm{ml} \text {. }\end{array}$} & \multicolumn{2}{|c|}{ Total nitrogen } & \multicolumn{3}{|c|}{ Amino-nitrogen } \\
\hline & & $\mathrm{mg} . / 100 \mathrm{ml}$. & $\%$ & mg./100 ml. & $\begin{array}{c}\text { After } \mathrm{HCl} \\
\text { hydrolysis } \\
\mathrm{mg} / 100 \mathrm{ml} \text {. }\end{array}$ & $\begin{array}{l}\text { Increase } \\
\text { after hydro- } \\
\text { lysis }(\%)\end{array}$ \\
\hline I & $9 \cdot 45$ & I 220 & $88 \cdot 34$ & $444 \cdot 7$ & $833 \cdot 3$ & $+87 \cdot 3$ \\
\hline II & 0.90 & II 9 & $8 \cdot 62$ & 63.0 & $83 \cdot I$ & $+3 I \cdot 9$ \\
\hline III & $0 \cdot 25$ & 24 & $I \cdot 74$ & I 4.4 & $17 \cdot 3$ & $+20 \cdot I$ \\
\hline IV & 0.15 & 18 & $I \cdot 30$ & $7 \cdot 4$ & $6 \cdot 8$ & $-8 . \mathrm{I}$ \\
\hline Sum & $10 \cdot 75$ & I $38 \mathrm{I}$ & $100 \cdot 0$ & $529 \cdot 5$ & $940 \cdot 5$ & $+77 \cdot 6$ \\
\hline Initial PCD & $11 \cdot 02$ & 1340 & - & $532 \cdot 7$ & 953.9 & $+79 \cdot 0$ \\
\hline
\end{tabular}

Table 7. Iron contents in PCD fractions obtained by gel chromatography on Sephadex $\mathrm{G} 25$ medium, elution buffer $0.05 \mathrm{M}-\mathrm{NH}_{4} \mathrm{HCO}_{3}$

$\mathrm{Fe}^{2+}$ determination with $O$-phenanthrolin.

$\begin{array}{lccc}\text { Fraction no. } & \begin{array}{c}\text { Dry matter } \\ \text { g./IO0 ml. }\end{array} & \mu \mathrm{g} . / \mathrm{ml} . & \mu \mathrm{g} . / \mathrm{g} . \text { dry matter } \\ \text { I } & 9.45 & 4.60 & 48 \\ \text { II } & 0.90 & 0.66 & 73 \\ \text { III } & 0.25 & \mathrm{I} \cdot 18 & 472 \\ \text { IV } & 0.15 & \mathrm{I} \cdot 56 & 1040 \\ \text { Initial PCD } & \mathrm{II} \cdot 2 & 7.80 & 69\end{array}$

Data on the sizes of the peptides in the different fractions were obtained by amino- $\mathrm{N}$ determination before and after acid hydrolysis. Resulting amino- $\mathrm{N}$ increase indicated that the fractions successively passing through the column contained decreasing quantities of cleavable peptide bonds. The decrease of amino- $\mathrm{N}$ in the 4 th fraction was associated with its tryptophan content, being destroyed by acid hydrolysis.

Iron content of the fractions. The preceding experiments showed a cation retention on gel and therefore the presence of iron in the different fractions was studied. Table 7 shows that all initially present iron left the column. Fraction I contained more than half the initial amount; but a calculation in reference to the dry matter revealed a higher $\%$ of iron leaving with the low-molecular weight groups. Irregular distributions of ions among the various peaks could distort the results of the cultivation tests with the peptide fractions, therefore an appropriate balancing of iron values in the culture media was indispensable.

Chromatographic analysis of the individual fractions. Paper chromatography showed that fractions I and II contained about I 2 well separated ninhydrin-positive substances each; fraction III formed one long smear from the start towards tyrosine, with a separated spot in the phenylalanine position (Pl. 2). Fraction IV contained tryptophan 


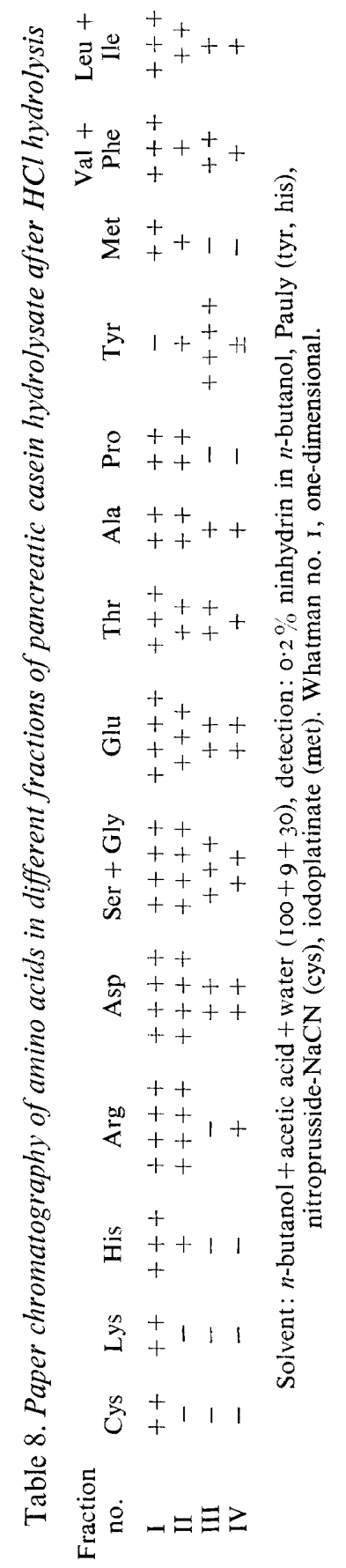


detectable with Ehrlich's reagent. Table 8 gives a schematic picture of the amino acids in the different fractions. It was characteristic that fraction I contained, apart from other amino acids, also amino acids of the sulphur group (cystine, methionine) but no tyrosine or tryptophan. The second group had a closely similar composition to the preceding fraction, but it contained no cystine or lysine though, in contrast to fraction I, traces of tyrosine were present. Fraction III consisted mainly of a Pauly-positive spot which disintegrated during acid hydrolysis into tyrosine and some other amino acids.

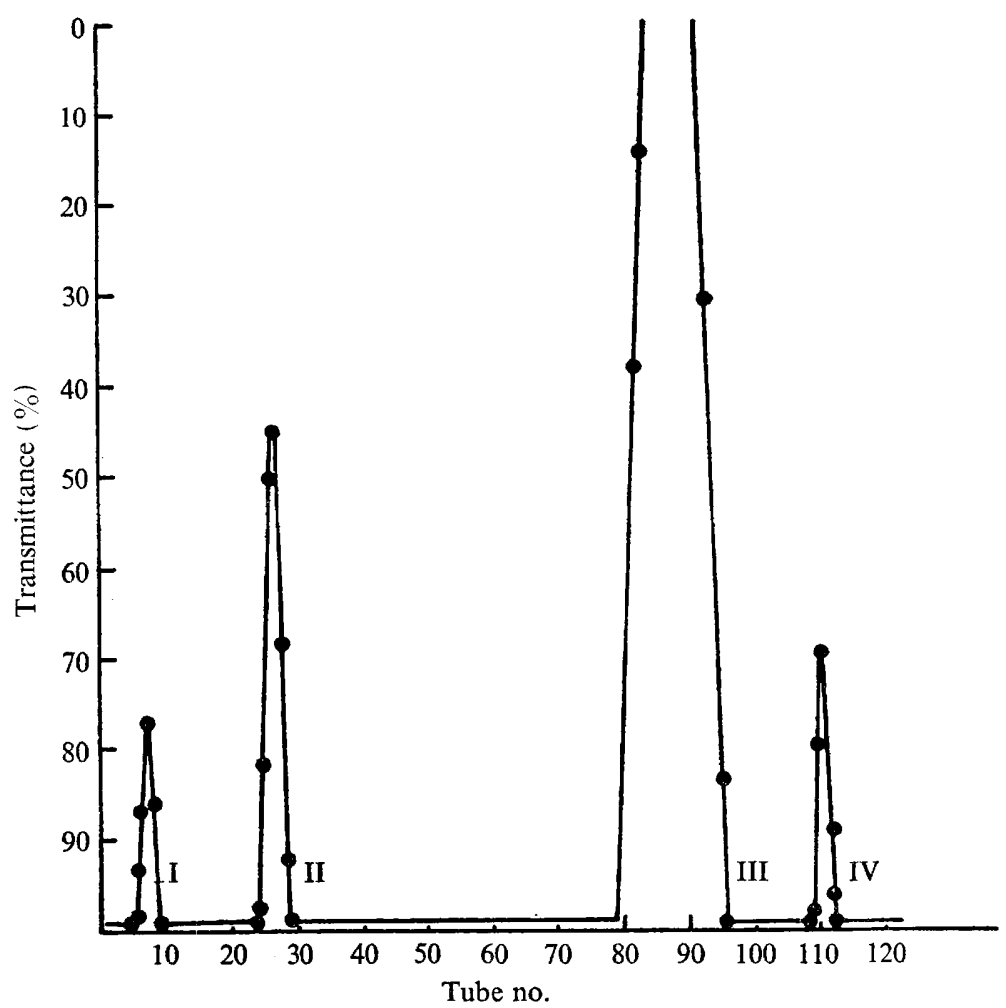

Fig. 3. Separation on Sephadex ion exchanger of the toxin-promoting 'third' fraction obtained by gel filtration of pancreatic casein digest through Sephadex G25, elution with $0.05 \mathrm{M}_{-} \mathrm{NH}_{4} \mathrm{HCO}_{3}$ (see Fig. 2). Column of DEAE-Sephadex A $25(\mathrm{I} \times 20 \mathrm{~cm}$.) in the acetate form. A $2 \mathrm{ml}$. sarnple containing $\mathrm{I} \cdot 2 \mathrm{mg}$. total $\mathrm{N}$ was applied on the bed. Elution with $0.1 \mathrm{M}$-collidine in acetate buffer, $\mathrm{pH} 7.8$, gradient in $\mathrm{pH} \mathrm{O} .1 \mathrm{M}$-acetic acid up to the 48 th test-tube, then I M-acetic acid. Flow rate $15 \mathrm{ml}$./h. approx. Detection with Moore-Stein ninhydrin reagent as modified by Rosen (1957), transmittance at $520 \mathrm{~nm}$.

Fractionation of peak III on DEAE-Sephadex. Fraction III obtained by fractionation of $50 \mathrm{ml}$. PCD was freeze-dried, dissolved in $20 \mathrm{ml}$. physiological saline and fractionated on DEAE-Sephadex A 25 column, by Carnegie's technique (196I). On the column $2 \mathrm{ml}$. samples of fraction III solution were spotted, containing about $\mathrm{I} \cdot 2 \mathrm{mg}$. total $\mathrm{N}$ Fractionation was done by gradient elution with collidine + acetate buffer, with $\mathrm{pH}$ line shift. Fig. 3 shows that the peptide group was again fractionated into four components which were analysed by paper chromatography. Paper chromatography of the individual groups, before and after acid hydrolysis, in an $n$-butanol + acetic acid + 
water solvent gave the following picture after detection with ninhydrin, Pauly's and Ehrlich's reagents: Peak I exhibited prior to $\mathrm{HCl}$ hydrolysis one Ehrlich-positive spot, tryptophan, which disappeared on hydrolysis, and serine + glycine appeared; peak II contained mainly free phe, traces of ser + gly, glu ac and tyr; peak III showed a long Pauly-positive smear, after $\mathrm{HCl}$ hydrolysis marked spots of tyr, ser + gly, asp ac, glu ac and one Pauly-positive spot under tyr, probably a product of tyrosine decomposition; peak IV contained free amino acids: asp ac, ser + gly and glu ac.

It is evident that the stimulating group consisted mainly of aromatic amino acids, with a predominant content of tyrosine and its peptides; free phenylalanine, a small quantity of peptide-bound tryptophan and to a lesser degree some free amino acids were also present.

\section{DISCUSSION}

The above-described results with Clostridium welchii show that fractionation of enzymic casein hydrolysate by molecular sieving can provide information about toxinogenic components in media. It seems promising to use for the separation of peptides the advantages offered by a highly cross-linked Sephadex gel, the choice of eluant being limited by the requirement of its easy elimination by freeze-drying.

The first series of experiments showed that the fractionation method applied by Phillips \& Gibbs (196I) to show the stimulating effect of some peptide fractions on the growth of Lactobacillus casei could not be used for cultivating Clostridium welchii. The culture medium prepared from a mixture of all fractions obtained by using ammonium hydroxide buffer as an eluant was capable of inducing growth, but toxin production was markedly inhibited. The reason for this failure could be sought in a retardation or adsorption of toxinogenic substances on the Sephadex. The adsorbed substances extractable by a weak acid showed a stimulatory effect on $\alpha$-toxin production. The organic portion of the extracts played an important part in the stimulatory action, but it represented a complex mixture of ninhydrin-positive aliphatic and aromatic substances, the separation and growth-testing of which would mean a laborious task which could not be resolved within a reasonable time. In the extracted active substance also calcium, magnesium and iron were found, but growth tests showed that a partial depletion of the nutrient medium of some cations did not offer a sufficient explanation for the toxin-promoting nature of the acetic acid extract. The quantity of these toxinogenic substances represented only a very small proportion of the original enzymic hydrolysate and seemed to be of a biocatalytic rather than of a nutritional nature.

We presume that the choice of an eluant which does not cause retention of toxinogenic substances on gel may facilitate the localization and definition of the active substances. Fractionation with ammonium hydrogen carbonate as an eluant did not induce retention of the substances required for full growth and toxin production. The first of four fractions obtained, consisting of the largest molecules and containing 85 to $90 \%$ of nitrogenous substances present, was able to induce full growth of the strain, but the production of toxin was depressed, proving again that the growth-promoting substances were not identical with the substances stimulating the formation of potent $\alpha$-toxin. Each of the further low-molecular groups was capable of increasing toxin titres, especially the third fraction which passed through the column. These results indicated the presence of different stimulating substances with less or more pronounced toxinogenic capacities. 
The question arises whether the stimulating effect is associated with peptides of a certain size only which can be easily metabolized by the microbe, or rather with their specific composition. Biochemical characterization of the obtained peptidic groups provides a partial explanation at least for that question. It must be emphasized that chromatographic analyses showed that separation of peptide groups by gel filtration did not proceed on the basis of molecular size only, but also according to the chemical nature of the substances. The known adsorption effect of gel on aromatic amino acids (Gelotte, I960; Determann \& Walter, 1968) played a part here.

Folin-positive peptide groups which first passed through the column contained not only the largest molecules but also almost all the essential amino acids except tyrosine and tryptophan. This might lead to a conclusion that it is the absence of the two aromatic amino acids which is responsible for the weak toxinogenesis. It should not be forgotten, however, that the second fraction containing no tryptophan and only traces of tyrosine exhibited an enhancing effect on toxin production, though it differed from fraction I mainly by the size of molecules. Most active appeared to be the third fraction containing the most tyrosine, both free and peptide-bound. This fraction mixed with fraction I fully restored the toxinogenic capacity of the strain. The last of the lowmolecular fractions, containing mostly tryptophan, was also capable of slightly stimulating toxin formation, but it was dispensable, as shown by the high toxin titres obtained in media prepared from fractions I + III exclusively. This finding was in conformity with the results of experiments on the cultivation of Clostridium welchii in Boyd's semi-defined medium (Boyd et al. I948); in this medium, containing acid hydrolysate enriched with cystine+tryptophan, we did not obtain $\alpha$-toxin production, while the addition of enzymic casein digest to the acid hydrolysate resulted in a marked lecithinase production (unpublished data). In this case, too, tryptophan was not an efficient factor for toxin formation.

Further fractionation of the third group of ion-exchange gel fractions showed that this group was a mixture of amino acids and peptides with a prevailing quantity of aromatic substances. When judging the potential toxinogenic effect of the different substances obtained by ion-exchange technique, the presence of a small quantity of tryptophan could be neglected since it was not indispensable for toxin formation. Phenylalanine detected in the active fraction did not seem to provoke stimulation of the whole third fraction; it was present in the first fraction from the Sephadex G 25 column, though its toxinogenic effect was very low. The quantitatively strongest substance to which a stimulatory effect could be ascribed was peptide-bound tyrosine. Similarly, as in many other cases (Kihara \& Snell, 1960; Prescott, Peters \& Snell, I953; Stone \& Hoberman, I953; Mikeš, Kakol, Zbrozyna \& Šorm, 1960), we can presume that the peptides influenced microbial metabolism more strongly than the free amino acids they contained. Peptide-bound amino acids are often better utilizable by the microbe for transpeptidation and proteosynthesis than free amino acids (Fry, 1955).

When comparing the chemical character of the toxinogenic substances retarded on gel during elution by an ammoniacal buffer with the nature of the active third fraction obtained $d_{j}$ on elution with ammonium hydrogen carbonate, we found that both were low molecular weight substances containing aromatic amino acids. The experiments so far do not permit us to draw definite conclusions about the identity of the two active components obtained by the different fractionation techniques.

Returning to the question about the nature of the active substances, it should be 
pointed out that, while the fraction with the larger tyrosine content showed a strong stimulation, there were several other low-molecular peptide groups which promoted toxin production. The toxinogenic effect of some substances resulting from enzymic splitting of casein was related primarily to the binding of amino acids in small peptides and secondly only to the specific amino acid composition. This finding explains, in part at least, the heterogeneity of the active substances found by several authors (Rogers \& Knight, 1946; Adams et al. 1947; Murata et al. I958; Jayko \& Lichstein, 1959). It can be assumed that the difficulties accompanying the attempt to obtain high $\alpha$-toxin yields in media from acid casein hydrolysate may be attributed to the absence of peptide-bound essential amino acids. Attempts are being made to replace the third active group with synthetic tyrosine peptides.

In the present work our attention was concentrated on the effect of nitrogenous products of casein cleavage. The influence of the quantitative cation distribution among the different peptide fractions should not be neglected. A higher percentage of cations leave the Sephadex column with the low molecular weight groups. The above experiments suggested that growth tests of peptide fractions must take into consideration the irregular distribution of cations, and their effect on growth and toxin production must be eliminated by an appropriate adjustment of nutrient media; but an influence of further trace cations cannot be excluded.

The authors want to acknowledge the skilful performance of chromatographs by Mrs Šindelářová, and the continual interest and support of Ing. Peterả.

\section{REFERENCES}

Adams, M. H. \& HendeE, E. D. (1945). Methods for the production of the alpha and theta toxins of Clostridium welchii. Journal of Immunology $\mathbf{5}, 249$.

Adams, M. H., Hendee, E. D. \& Pappenhermer, A. M. (1947). Factors involved in production of Clostridium welchii alpha toxin. Journal of Experimental Medicine 85, 701 .

Boyd, M. J., Logan, M. A. \& Tytell, A. A. (I 948). The growth requirements of Clostridium perfringens (welchii) вр $6 \mathrm{~K}$. Journal of Biological Chemistry 174, $10 \mathrm{I} 3$.

CARnegie, P. R. (1961). Separation of low molecular weight peptides from amino acids on 'DEAESephadex'. Nature, London $\mathbf{1 8}, 658$.

Determann, H. \& Walter, I. (1968). Source of aromatic affinity to 'Sephadex' dextran gels. Nature, London $219,604$.

FrY, B. A. (1955). The Nitrogen Metabolism of Micro-organisms. London: Methuen and Co. Ltd.

Gelotte, B. (1960). Studies on gel filtration. Sorption properties of the bed material Sephadex. Journal of Chromatography 3, 330.

Hais, I. M. \& MACEK, K. (1959). Papirova Chromatografie. Praha, ČSSR: Nakladatelství Československé Akademie Vẽd.

van Heyningen, W. E. (I94I). The biochemistry of the gas gangrene toxins. I. Estimation of the alphatoxin of Clostridium welchii, type A. Biochemical Journal 35, 1246.

JAYKO, L. G. \& LiChSTEIN, H. C. (I959). Nutritional factors concerned with growth and lecithinase production by Clostridium perfringens. Journal of Infections Diseases ro4, I42.

KÉmeny, L. \& Illés, E. (1952). Wertbemessung der Perfringens Sera mit der Lecitho-vitellinprobe. Acta Veterinaria Academiae Scientiarum Hungaricae 2, 79.

Killara, H. \& SNell, E. E. (1960). Peptides and bacterial growth. IX. Release and double inhibition with single peptides. Journal of Biological Chemistry 235, 145.

logan, M. A., Tytell, A. A., Danielson, J. S. \& Griner, A. M. (I945). Production of Clostridium perfringens alpha-toxin. Journal of Immunology 51, 317.

Lowry, O. H., Rosebrough, N. J., Farr, A. L. \& Randall, R. J. (1951). Protein measurement with the Folin phenol reagent. Journal of Biological Chemistry r93, 265. 
MACFARLANe, M. G. \& KNIGHT, B. C. J. G. (194I). The biochemistry of bacterial toxins. I. Lecithinase activity of Clostridium welchii toxins. Biochemical Journal 35, 884.

Mikeš, O., KaKol, I., ZBRozYNA, A. J. \& ŠoRM, F. (1960). On proteins. LVIII. Growth stimulating peptides from neutral fraction of a partial acid hydrolysate of chymotrypsinogen. Collection of Czechoslovak Chemical Communications 25, 1938.

Murata, R., Yamada, T. \& Kameyama, S. (1 958). Production of alpha-toxin of Clostridium perfringens. III. The role of certain unidentified factors on the toxin production. Japanese Journal of Medical Science and Biology II, 427.

Pappenheimer, A. M. \& Shaskan, E. (I944). Effect of iron on carbohydrate metabolism of Clostridium welchii. Journal of Biological Chemistry $\mathbf{1 5 5}, 265$.

Phillips, A. W. \& GibBs, P. A. (1961). Techniques for the fractionation of microbiologically active peptides derived from casein. Biochemical Journal 8I, 551 .

Prescott, J. M., Peters, J. V. \& Snell, E. E. (1953). Peptides and bacterial growth. V. Serine peptides and growth of Lactobacillus delbrueckii. Journal of Biological Chemistry 202, 533.

Rogers, R. J. \& KNIGHT, B. C. J. G. (1946). The recognition of material present in horse muscle affecting the formation of $\alpha$-toxin by a strain of Clostridium welchii. Biochemical Journal 40, 400.

Rosen, H. (1957). A modified method of ninhydrin colorimetric analysis for amino acids. Archives of Biochemistry and Biophysics 67, 10.

Schroeder, W. A., KaY, L. M. \& Mills, R. S. (1950). Quantitative determination of amino acids by iodometric titration of their copper salts. Anaiytical Chemistry 22, 760.

SHANKAR, K. \& BARD, R. C. (1952). The effect of metallic ions on the growth and morphology of Clostridium perfringens. Journal of Bacteriology 63, 279.

SpRINCE, H. (1960). A modified Ehrlich benzaldehyde reagent for detection of indoles on paper chromatograms. Journal of Chromatography 3, 97.

Stavri, D., Bittner, J. \& Ficiu, S. (1964). Méthode simple pour l'obtention constante d'une alphatoxine perfringens à titre élevé. Archives Roumaines de Pathologie Expérimentale et de Microbiologie 23, 1025 .

Stone, D. \& Hoberman, H. D. (1953). Utilization of proline peptides by a prolineless mutant of Escherichia coli. Journal of Biological Chemistry 202, 203.

TAYLOR, A. W. \& StEWART, J. (I94I). Toxin produced by Clostridilum welchii in a simple medium. Journal of Pathology and Bacteriology 53,87.

VANĚČEK, J. (196I). Eluce papírových chromatogramu. In: Mikeš a kolektiv. Př́rručka Laboratorních Chromatografických Metod. Praha, ČSSR: Státní Nakladatelství Technické Literatury.

\section{EXPLANATION OF PLATES}

\section{Plate i}

Paper chromatography of the active substance adsorbed on Sephadex G 25 bed, eluant $0.2 \mathrm{M}-\mathrm{NH}_{3}$, subsequent elution with 0.1 M-acetic acid. The acetic effluent separated on Whatman no. 3 paper is shown to the left. The paper strip was cut into 6 sections I-VI and peptide groups were eluated with water, then $\mathrm{HCl}$ hydrolysed and rechromatographed on Whatman no. I paper. A-D are standard mixtures of amino acids. Solvent: $n$-butanol + acetic acid + water $(100+9+30)$; detection: $0 \cdot 2 \%$ $(\mathrm{w} / \mathrm{v})$ ninhydrin solution in $n$-butanol.

\section{Plate 2}

Paper chromatography of fractions I-IV obtained by gel filtration of pancreatic casein digest through Sephadex G 25, elution with $0.05 \mathrm{M}-\mathrm{NH}_{4} \mathrm{HCO}_{3}$. Whatman no. I paper, solvent system $n$-butanol+ acetic acid + water $(100+9+30)$, detection with $0.2 \%(w / v)$ solution of ninhydrin in $n$-butanol. Fraction IV before and after $\mathrm{HCl}$ hydrolysis is shown to the right. Detection of tryptophan with $p$-dimethylaminobenzaldehyde. (Samples after $\mathrm{HCl}$ hydrolysis are designated with an index ' $\mathrm{H}^{\text {'.) }}$ 


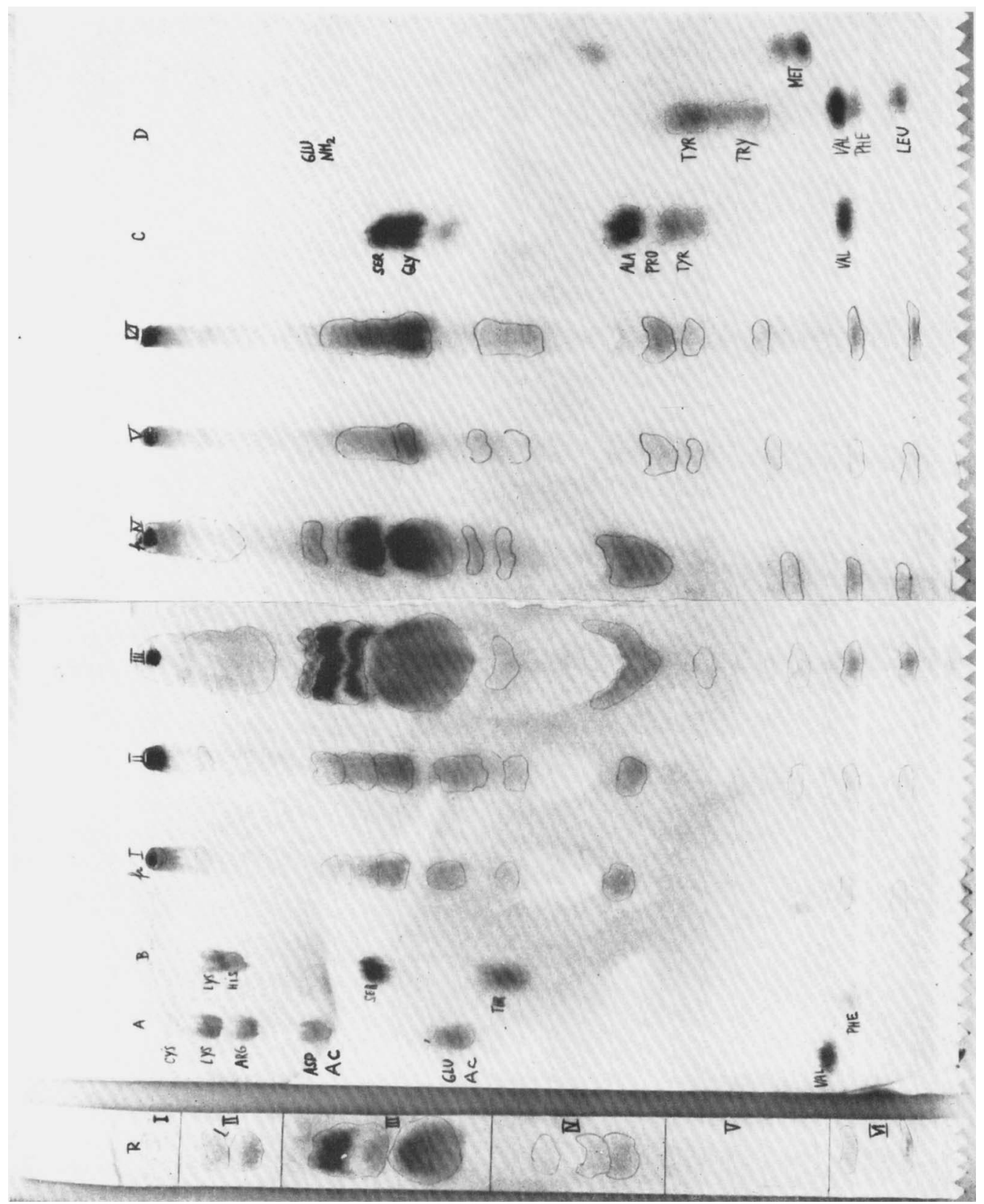

K. NEKVASILOVÁ, J. ŠÍDLO AND J. HÁLA 


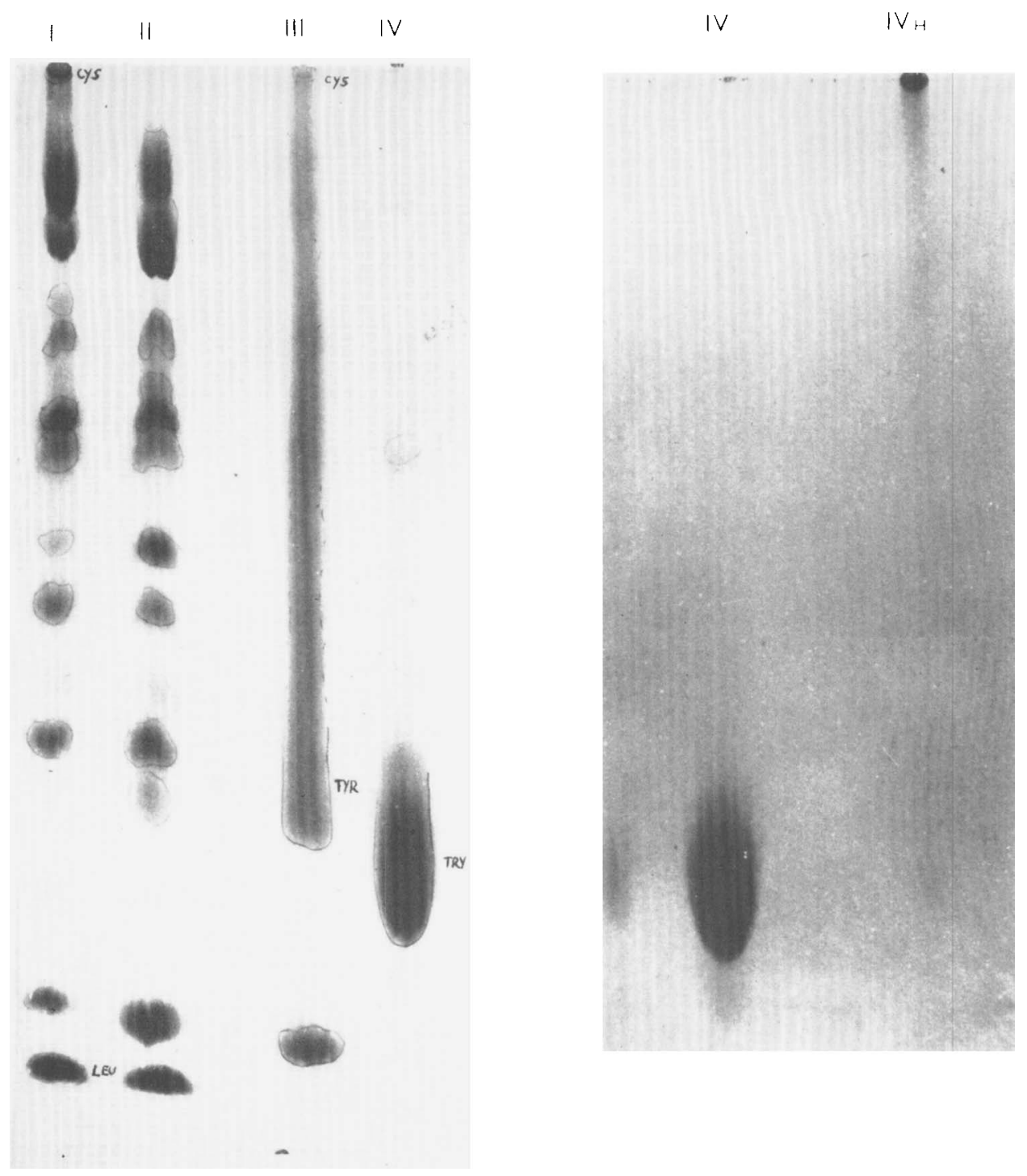

K. NEKVASILOVÁ, J. ŠÍDLO ANU J. HÁZA 